\title{
Helicobacter spp. in domestic cats: identification and relationship with anatomical and histopathological gastric changes in animals of blood group $\mathrm{A}^{1}$
}

\author{
Daniela A. Sousa ${ }^{2 *}$, Clarice M. Cascon ${ }^{3}$, Marcela F.V. Mello ${ }^{3}$, Juliana S. Leite ${ }^{3}$, Miguel \\ A. Medeiros ${ }^{4}$, Ana Beatriz M. Fonseca ${ }^{5}$ and Ana Maria R. Ferreira ${ }^{2,3}$
}

\begin{abstract}
Sousa D.A., Cascon C.M., Mello M.F.V., Leite J.S., Medeiros M.A., Fonseca A.B.M. \& Ferreira A.M.R. 2017. Helicobacter spp. in domestic cats: identification and relationship with anatomical and histopathological gastric changes in animals of blood group A. Pesquisa Veterinária Brasileira 37(12):1467-1473. Departamento de Patologia e Clínica Veterinária, Faculdade de Veterinária, Universidade Federal Fluminense, Rua Vital Brazil 64, Niterói, RJ 24230-340, Brazil. E-mail: anatopatovet@vm.uff.br

The aim of this study was to evaluate the presence of gastric Helicobacter-like organisms and the endoscopic and histopathological changes in domestic cats with blood type A. Samples from the stomach antrum, body and fundus were collected from 32 mixed-breed stray domestic cats using gastroscopy. Urease testing and cytological analysis were performed in fresh samples. Tissue sections were processed and stained with hematoxylin and eosin (H\&E) and the Warthin-Starry (WS) silver staining methods for histopathological examination. Helicobacter spp. were detected in $100 \%$ of samples subjected to silver staining and cytological analysis, and in $96.9 \%$ of samples subjected to urease testing. In $87.5 \%$ of the cats, mononuclear inflammatory-cell infiltrates were identified. The graduation and distribution of inflammatory infiltrates in these cats revealed mild (78.1\%) to moderate (9.4\%) inflammatory changes in at least one gastric region. These changes were independent of the colonization score. Hyperplasia of the lymphoid follicles was detected in three cats. Cats of blood group A are often colonized by Helicobacter spp. and the macroscopic and microscopic findings are consistent with studies in domestic cats reported to date, concluding that the most common blood group in cats is not associated with high susceptibility to symptomatic gastritis.
\end{abstract}

INDEX TERMS: Helicobacter spp., domestic cats, blood group A, endoscopy, feline, gastritis, histopathology.

RESUMO.- [Helicobacter spp. em gatos domésticos: identificação e relação com alterações gástricas anatômicas e histopatológicas em animais de sangue tipo A.] 0 ob-

\footnotetext{
${ }^{1}$ Received on November 19, 2015.

Accepted for publication on December 12, 2016.

${ }^{2}$ Programa de Pós-Graduação em Clínica e Reprodução Animal, Departamento de Patologia e Clínica Veterinária, Faculdade de Veterinária (FV), Universidade Federal Fluminense (UFF), Rua Vital Brazil Filho 64, Santa Rosa, Niterói, RJ 24230-340, Brazil. *Corresponding author: anatopatovet@vm.uff.br, dani.a.sousa@hotmail.com

${ }^{3}$ Departamento de Patologia e Clínica Veterinária, FV-UFF, Rua Vital Brazil Filho 64, Santa Rosa, Niterói, RJ 24230-340, Brazil.

${ }^{4}$ Departamento de Patologia, Faculdade de Veterinária, Universidade Castelo Branco, Avenida Santa Cruz 1631, Realengo, Rio de Janeiro, RJ 21710-250, Brazil.

${ }^{5}$ Departamento de Estatística, Instituto de Matemática, UFF, Rua Professor Marcos Waldemar de Freitas Reis s/n, Bloco H, Campus do Gragoatá, São Domingos, Niterói, RJ 24210-201, Brazil.
}

jetivo deste estudo foi avaliar a presença de organismos semelhantes a Helicobacter e as alterações endoscópicas e histopatológicas em estômago de gatos domésticos de sangue tipo A. Amostras de antro, corpo e fundo gástricos foram coletadas de 32 gatos, sem raça definida, não domiciliados através de gastroscopia. Teste de urease e análise citológica foram realizados em amostras frescas. Secções teciduais foram processadas e coradas com hematoxilina e eosina e pela prata pelo método de Warthin-Starry para avaliação histológica. Helicobacter spp. foi detectado em $100 \%$ das amostras submetidas às análises citológicas e coloração pela prata e em $96,9 \%$ das amostras submetidas ao teste de urease. Em 87,5\% dos gatos foi identificado infiltrado inflamatório mononuclear. A graduação e distribuição do infiltrado inflamatório nestes gatos revelaram alterações leves $(78,1 \%)$ a moderada $(9,4 \%)$ em pelo menos uma região gástrica. Estas alterações eram independentes do escore de 
colonização. Hiperplasia de folículos linfoides foram detectadas em 3 gatos. Gatos do grupo sanguíneo A são frequentemente colonizados por Helicobacter spp. e os achados macro e microscópicos são consistentes com estudos em gatos domésticos realizados até a presente data. Conclui-se que o grupo sanguíneo mais comum em gatos não está associado com uma alta susceptibilidade a gastrite sintomática causada por Helicobacter spp.

TERMOS DE INDEXAÇÃO: Helicobacter spp., felinos, grupo sanguíneo A, endoscopia, gastrite, histopathologia.

\section{INTRODUCTION}

Because Helicobacter pylori ( $H$. pylori) has been described as a cause of gastric diseases in humans, the number of studies on the pathophysiology of these disorders were quite intensified, leading to the description of various related bacterial species in different mammals. The studies in humans have demonstrated an association of the ABO blood group system with susceptibility and/or resistance to such diseases (Coelho \& Diniz 2010). In individuals belonging to the blood group 0 of the $\mathrm{ABO}$ system, it was observed a greater predisposition to the development of gastric diseases caused by $H$. pylori (Mattos et al. 2010, Jaff 2011). The gastric Helicobacter spp. infection in mixed-breed cats has also demonstrated a high association with mild to moderate gastritis (Geyer et al. 1993, Papasouliotis et al. 1997, Neiger et al. 1998, Araujo et al. 2010). Nevertheless, up to this day, there have been no studies in the literature including the description of Helicobacter spp. infection, gastric lesions and specific blood types in domestic cats. In 1950, it was reported the existence of a blood group system in felines, which consists of two kinds of naturally occurring alloantibodies. These two types received the nomenclature A and B, and later on, in 1980, a third blood type was described in cats, and named as AB. There are no reports of cats that do not have erythrocytary antigens - blood type 0 or zero, and studies in different countries show that most mixed-breed cats belong to blood group A (Jaff 2011). Therefore, the aim of the present study was to evaluate the presence of gastric Helicobacter-like organisms (GHLOs) and endoscopic and histopathological changes in domestic undomiciled cats with blood type A.

\section{MATERIALS AND METHODS}

Ethics statement. This study was approved by the Ethics Committee on Animal Use (CEUA, Comite de Ética no Uso de Animais) of Universidade Federal Fluminense, Niterói, Brazil, under the protocol number 48/2011.

Animals. Thirty-two undomiciled domestic cats (12 males and 20 females), with body weight $\geq 2.0 \mathrm{~kg}$, from a shelter for abandoned animals, underwent gastroscopy before the sterilization routine.

Collection and blood typing. A sample of $1.0 \mathrm{~mL}$ of blood was collected from the cephalic or femoral vein of cats and was sent, in a test tube containing EDTA, to a clinical lab for blood typing. For each sample, $30 \mu \mathrm{L}$ of blood was mixed with $30 \mu \mathrm{L}$ of wheat germ lectin (Triticum vulgaris lectin) in a test tube, in order to induce agglutination of cat blood of type B and AB. Samples from the cats whose blood did not undergo agglutination were selected for this study, because they belonged to blood group A.
Gastroscopy and gastric biopsy. The catstwere fasted for $12 \mathrm{~h}$ before procedure. The induction and maintenance of anesthesia were performed with tiletamine-zolazepam association (Zoletil $\left.^{\circledR} 100\right)$. For induction it was used the dose of $3.75 \mathrm{mg} / \mathrm{kg}$ $(0.075 \mathrm{ml} / \mathrm{kg})$ intramuscular (IM) and for maintenance a dose of $2.5 \mathrm{mg} / \mathrm{kg}(0.05 \mathrm{ml} / \mathrm{kg})$ intravenous (IV), diluted in $3 \mathrm{ml}$ of saline solution, and reapplied when the animal presented superficialization signals. The assessment and collection of gastric mucosa samples were performed using a pediatric endoscope (Pentax FG-28C) of 9.0-mm diameter, with a 2.0-mm biopsy channel. The evaluation of the gastric mucosa was based on the WSAVA International Gastrointestinal Standardization Group (Washabau et al. 2010). At least two samples of the mucosa from the gastric body, antrum, and fundus were collected and individually stored. Between the procedures performed on different animals, all endoscopes, biopsy forceps, and cytology brushes were sterilized by immersion in glutaraldehyde for $20 \mathrm{~min}$ and then rinsed under tap water.

Rapid urease test. The mucosa samples from the stomach antrum, body, and fundus of each cat were collected and individually placed in a microtube of Renylab Uretest ${ }^{\circledR}$ commercial kit (Renylab Chemicals \& Pharmaceuticals) according to the manufacturer's instructions. Samples that had changed color from yellow to magenta were considered positive for Helicobacter spp. The reading of results was performed at three time points $(30 \mathrm{~min}, 2 \mathrm{~h}$, and $8 \mathrm{~h}$ ) and the timing of color changes was analyzed for a possible association with the amount of bacteria in the sample.

Cytopathology. Samples for cytological examination were obtained during gastroscopy via insertion of a cytology brush into the biopsy channel and brushing on the mucosa with a subsequent preparation of the smear material for microscopy on slides. Samples of each gastric region were separately collected and were air dried for later immersion in carbol fuchsin for $60 \mathrm{~s}$ and followed by washing in distilled water. The samples were examined under a light microscope with a $40 \times$ objective in search of pink stained GHLOs. The sample was considered positive when there was at least one bacterial cell with morphology matching to the genus Helicobacter.

Histopathology. Immediately after collection, the samples were fixed in $10 \%$ buffered formalin for 24 to 48 hours for processing and paraffin embedding. Histological sections 3-5 $\mu \mathrm{m}$ in thickness were stained with hematoxylin and eosin (HE) and the Warthin-Starry (WS) silver staining method. The presence and intensity of inflammatory cells were evaluated in H\&E stained tissue sections under a light microscope with a $40 \times$ objective. The type of inflammatory infiltrate was characterized and the cells were counted and classified according to the following scale: 0 (no change), up to 20 inflammatory cells per field; 1 (mild gastritis), 11-50 inflammatory cells per field; 2 (moderate gastritis), 51-100 inflammatory cells per field; and 3 (severe gastritis), >100 inflammatory cells per field (Day et al. 2008). Spiral and black GHLOs were counted in five fields of WS silver staining histological sections. The colonization density of GHLOs was scored according to Araujo et al. (2010) as: 0 (no infection), 1 (up to 10 GHLOs), 2 (from 10 to 50 GHLOs), 3 (from 51 to 100 GHLOs), 4 (from 101 to 200 GHLOs), 5 (>200 GHLOs).

Statistical analysis. The chi-square test, McNemar's test and the Cramer coefficient was used. Level of significance was set to $5 \%$.

\section{RESULTS}

\section{Endoscopic appearance of the gastric mucosa}

Of the 32 animals evaluated, eight (25\%) showed alterations in the gastric mucosa. Of these, six had mild endos- 
copic gastritis and the other two animals showed moderate endoscopic pangastritis (Table 1). The other 24 (75\%) animals had intact gastric mucosa with pale pink color and soft folds in the region of the stomach body.

\section{Rapid urease test}

In the urease test, 31cats (96.9\%) showed positive results in the samples of the three gastric regions studied and one cat (3.1\%) had negative results in the three samples tested (Table 2).

Table 1. Changes observed in different gastric regions of domestic cats during gastroscopy

\begin{tabular}{cccc}
\hline Animal ID & GF & GB & GA \\
\hline 1 & - & - & HY (1) \\
2 & - & - & HY (1) \\
3 & HY (1) & - & - \\
4 & - & ER/UL (1) & - \\
5 & ER(1) & - & - \\
6 & ER (1) & - & - \\
7 & HY/ED (2) & HY/ED (2) & HY/ED (2) \\
8 & HY/ED (2) & HY/ED (2) & HY/ED (2)
\end{tabular}

$\overline{\mathrm{GF}}=$ gastric fundus, $\mathrm{GB}=$ gastric body, $\mathrm{GA}=$ gastric antrum, $\mathrm{HY}=$ hyperemia, $\mathrm{ED}=$ edema, $\mathrm{ER}=$ erosion, $\mathrm{UL}=$ ulcer; 1 = mild, 2 = moderate.

Table 2. Urease test results. The relationship between time elapsed until a color change and the percentage of samples of each gastric region of domestic cats showing positivity for Helicobacter spp.

\begin{tabular}{lccc}
\hline \multicolumn{1}{c}{ Color change } & \multicolumn{3}{c}{ Gastric region } \\
\cline { 2 - 4 } & Antrum & Body & Fundus \\
\hline Up to 30 min & $17(54.8 \%)$ & $12(38.7 \%)$ & $19(61.3 \%)$ \\
From 30 min to 2h & $5(16.1 \%)$ & $10(32.2 \%)$ & $5(16.1 \%)$ \\
From 2 h to 8 h & $9(29.1 \%)$ & $9(29.1 \%)$ & $7(22.6 \%)$ \\
Negative & 1 & 1 & 1
\end{tabular}

Min $=$ minutes, $\mathrm{b}-\mathrm{h}=$ hours .

Table 3. The frequency of colonization density of GHLOs in the gastric regions of the cats

\begin{tabular}{lccccc}
\hline Gastric & \multicolumn{5}{c}{ The score corresponding to the amount of Helicobacter spp. found } \\
\cline { 2 - 6 } Region & 1 & 2 & 3 & 4 & 5 \\
\hline Antrum & $3.1 \%$ & $21.9 \%$ & $21.9 \%$ & $31.2 \%$ & $21.9 \%$ \\
Body & $6.3 \%$ & $15.6 \%$ & $9.4 \%$ & $21.9 \%$ & $46.8 \%$ \\
Fundus & $3.1 \%$ & $15.6 \%$ & $12.5 \%$ & $34.4 \%$ & $34.4 \%$
\end{tabular}

\section{Cytopathology}

In all samples, the cytological examination showed the presence of at least one bacterial cell with morphology resembling the genus Helicobacter (Fig.1); these data indicate $100 \%$ of positive results among the studied cats.

\section{Histopathology}

In the histopathological analysis of the inflammatory infiltrate, 4 cats $(12.5 \%)$ showed no changes in any of the examined gastric regions. Mononuclear cells infiltrates were identified in 28 cats (87.5\%). In 25 cats $(78.1 \%)$, there was a mild infiltrate and in 3 cats (9.4\%) there was a moderate infiltrate in at least one gastric region. This assay revealed the presence of lymphocytes and plasma cells (Fig.2). Eight samples from the antrum, 11 from the body, and nine from the fundus had a score of 0 . The score of 1 was assigned to 24 samples from the antrum, 20 samples from the body, and 21 samples from the fundus. The score of 2 was assigned to only one sample from the body and two from the fundus. The score of 3 was not assigned to any of the samples. Therefore, the samples were classified as either mild lymphoplasmacytic gastritis (score 1) or moderate lymphoplasmacytic gastritis (score 2).

In the assessment of the lymphoid follicles, only two samples from the antrum, one from the body, and three from fundus showed hyperplasia of lymphoid follicles. These samples were from only four animals.

Regarding the quantification of GHLO stained using the WS method, the body region showed the largest number of bacterial cells, followed by the gastric fundus and the gastric antrum as described in Table 3.

All samples of the mucosa from the gastric antrum, body, and fundus that were stained with WS revealed the presence of bacteria with morphology resembling the genus Helicobacter, confirming the results observed in the cytological assay (Fig.3).

\section{Relation between diagnostic methods}

Urease and WS stain. When comparing the urease test and histological analysis with the WS stain using Cramer's $V$ statistic, the $p$ value was 0.000 in the antrum, 0.010 in the body, and 0.000 in the fundus, showing a correlation between the time elapsed before a color change in the urease test and the number of gastric GHLOs in each region (Fig.4).

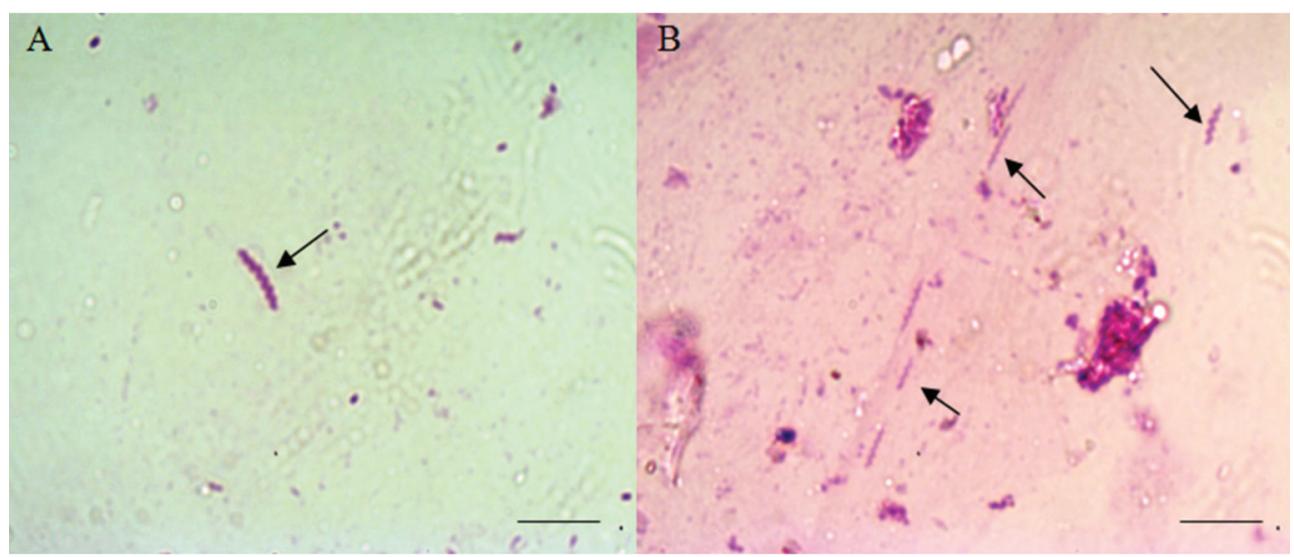

Fig.1. Gastric Helicobacter-like organism in domestic cats cytological smear (arrows). Carbol Fuchsin staining, scale bar $=10 \mu \mathrm{m}$. 

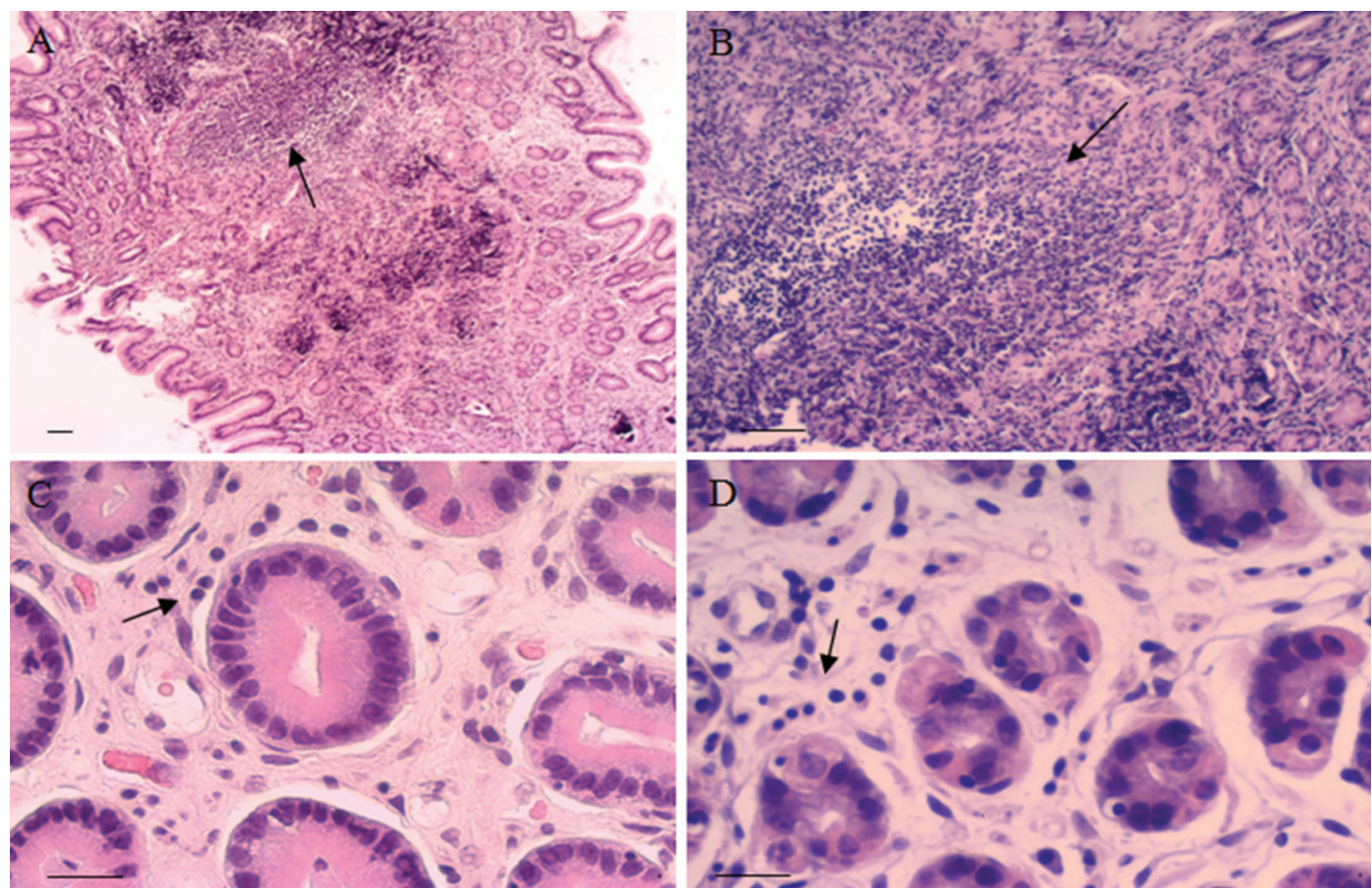

Fig.2. Inflammatory cells in the gastric mucosa of domestic cats. Hematoxylin and eosin staining. (A,B) Lymphoid follicle. (C,D) Lymphocytic inflammatory infiltrate in the lamina propria of the mucosa. $(A) B a r=50 \mu \mathrm{m} .(B, C, D) B a r=20 \mu \mathrm{m}$.

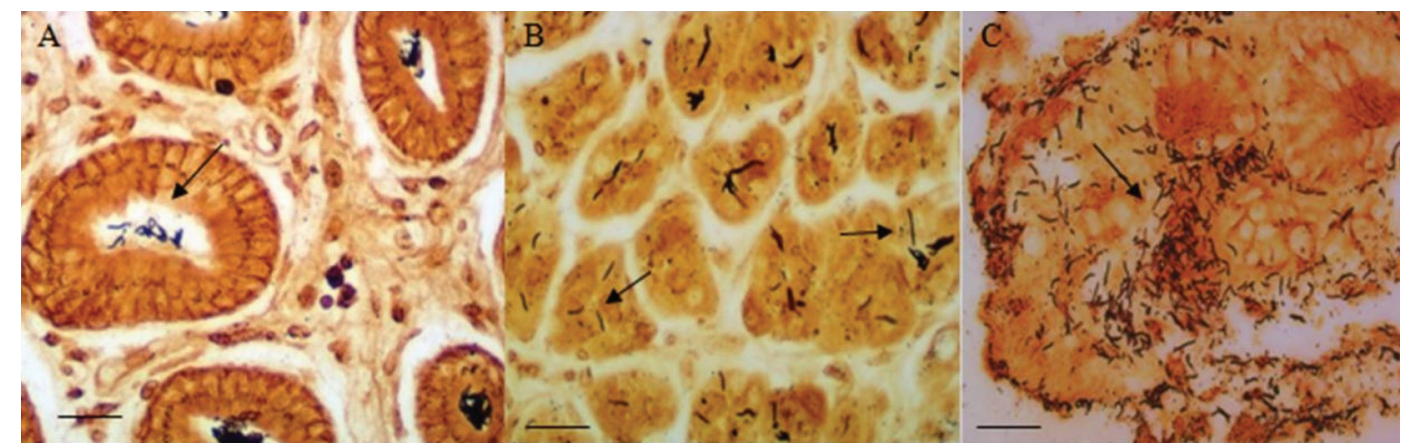

Fig.3. Colonization by gastric Helicobacter-like organisms (GHLOs) in the gastric mucosa of domestic cats. Warthin-Starry Silver staining. (A) Fundus region showing GHLOs in the glandular lumen. (B) Gastric body region showing GHLOs of varying sizes. (C) Fundus region, showing GHLOs marked in black on the surface mucus. $(A, B, C) B a r=20 \mu \mathrm{m}$.

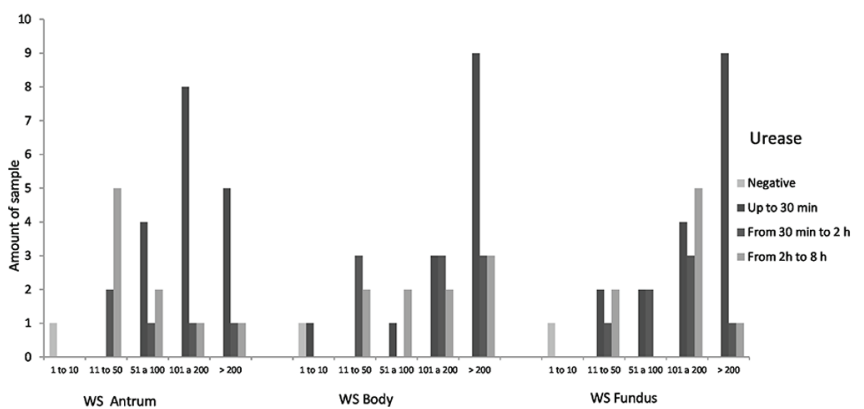

Fig.4. A histogram representing the relationship between time elapsed before a color change in the urease test and the colonization score (Warthin-Starry) in each sample of each gastric region of domestic cats.

HE and WS. The observation between histopathological samples stained with WS and HE using the Cramer's V statistic, was obtained $p=0.454$ in the antrum, $p=0.195$ in the body, and $p=0.501$ in the fundus; therefore, there was no correlation between the inflammatory infiltration score and number of gastric GHLOs in each gastric region (Fig.5).

\section{DISCUSSION}

This study shows the occurrence of Helicobacter spp. in $>90 \%$ of mixed-breed cats; this finding is in agreement with other studies in different countries (Papasouliotis et al. 1997, Akhtardanesh et al. 2006, Takemura et al. 2007, Araujo et al. 2010). One factor that may contribute to the spread of microorganisms among felines, including Helicobacter spp., is the habit of licking each other. One of the alleged routes of transmission of these bacteria is the direct oral route (Goh et al. 2011), which may explain the high percentage of infected animals found in different studies.

The urease test proved highly sensitive, detecting the presence of Helicobacter spp. in 31 of 32 cats. This negative cat had positive results for the cytological analysis and histophatology stained with silver (WS) show the presence 


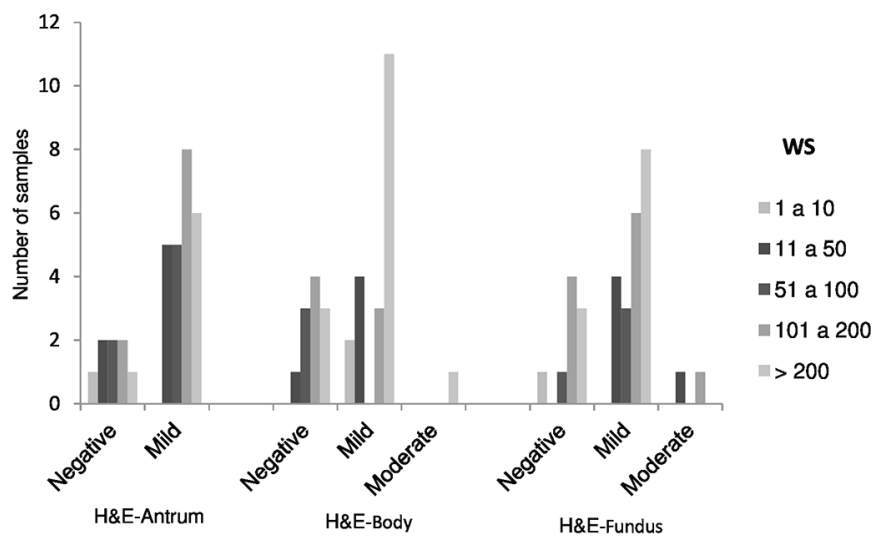

Fig.5. A histogram representing the relationship between the number of inflammatory cells and the score of colonization in each gastric region of domestic cats. Negative $=$ up to 10 inflammatory cells per field; mild $=11-50$ inflammatory cells per field; moderate $=51$ to 100 inflammatory cells per field.

of GHLOs but with a very low number of bacteria reaching only score 1 in all samples. Over $70 \%$ of the samples of all gastric regions yielded positive results in the urease test within $2 \mathrm{~h}$, and the color change occurred more rapidly in the samples with higher density of GHLOs. This finding leads us to the conclusion that the number of microorganisms influences the speed of degradation of the test urea, thereby showing a faster positive result (Fig.4).

In this study, all samples (100\%) yielded a positive result in cytopathology and histopathological examination with silver staining (WS), showing that these tests have high sensitivity. This is in agreement with other studies showing that cytopathology and silver stained samples (WS) are highly sensitive tests for detection of the genus Helicobacter (Takemura et al. 2007, Araujo et al. 2010).

The highest percentage of colonization by Helicobacter spp. in the gastric mucosa was observed in the body region followed by the fundus, which was in line with other studies in cats (Takemura et al. 2007, Araujo et al. 2010). In this study, $>50 \%$ of all regions had the colonization scores 4 and 5 , whereas only $6.3 \%$ of the samples from the body region and $3.1 \%$ from the antrum and fundus had a score of 1 . Therefore, we can say that undomiciled cats have the gastric mucosa with colonization by Helicobacter spp. at the moderate to intense level.

The results of macroscopic evaluation by endoscopy, showed changes like hyperemia, edema, erosion and/ or ulcer in $25 \%$ of the animals. Nonetheless, when assessing microscopic changes, inflammatory infiltrate was observed in $87.5 \%$ of the animals. These data show that the macroscopic and microscopic results are not related in the evaluation of the presence of gastritis. This finding is in agreement with the results of obtained by Akhtardanesh et al. (2006), who observed macroscopic changes in only $26.3 \%$ of animals, while histopathological changes were found in $66.7 \%$ of the studied samples.

The presence of a mild to moderate inflammatory infiltrate found in different gastric regions is in line with other studies (Geyer et al. 1993, Takemura et al. 2007, Araujo et al. 2010). In the present research the inflammatory infil- trate was not correlated with the density of colonization showing similar results reported by Akhtardanesh et al. (2006) and Neiger et al. (1998) but different from findings of other authors, who reported existence of this association (Otto et al. 1994, Happonen et al. 1996). This suggests that the different Helicobacter species can induce different intensities of inflammatory responses, since these studies there was no identification at the species level.

The hyperplasia of lymphoid follicles was found in only four animals; this incidence is lower than the incidence reported in studies with feline gastric samples collected during necropsy (Otto et al. 1994, Araujo et al. 2010). In the present study, the fact that the samples were collected using a pediatric endoscope may have contributed to the insufficient detection of hyperplastic lymphoid follicles. This may be due to the thickness of the samples that is much smaller compared with the samples collected during necropsy. The small samples were sufficient to obtain results in the rapid urease test and cytological and histopathological analysis with silver staining (WS) for evaluation of possible infection with Helicobacter spp. Some gastric samples did not have sufficient thickness to examine the entire length of the lamina propria; this situation may have reduced the actual number of detected hyperplastic lymphoid follicles. Some authors also reported that the detection sensitivity of hyperplasia of lymphoid follicles is lowest in samples collected using endoscopy (Neiger and Simpson 2000).

Some studies showed that several species of Helicobacter and different strains of the same species may not necessarily cause similar changes in gastric regions. The changes caused by H. pylori and $H$. felis are more pronounced than those caused by H. heilmanni (Scanziani et al. 2001). It is possible that the animals in this study were infected with less pathogenic species of Helicobacter spp. such as H. heilmannii, which is the most common Helicobacter species in cats.

In this study was observed that cats with blood group A are often infected with Helicobacter spp., but there was no correlation between the colonization score of the gastric regions and inflammatory infiltrate score observed. Studies in humans with gastric symptoms show that people with blood group $\mathrm{O}$ are more susceptible to infection with $H$. pylori and to relevant gastrointestinal complications and/ or have a cellular and immune response stronger than that of individuals with others blood types from the ABO group (Jaff 2011). Therefore, this study was conducted with only one blood group of the feline AB system. The group A was selected for the ease of finding individuals with this group, which was demonstrated in a study on blood groups of mixed-breed cats in the city of Rio de Janeiro; $94.8 \%$ of them belong to group A (Medeiros et al. 2008). Other studies have shown that most of mixed-breed cats in several countries also belong to this group (Hohenhaus 2004). In the present study, the more frequent blood group is often associated with colonization by GHLOs but the susceptibility of such cats to the relevant diseases is low.

Although the transmission of Helicobacter spp. from cats to human has been proposed (Dieterich et al. 1998, van Loon et al. 2003, Pregel et al. 2008, Haesebrouck et al. 
2009), research shows that the incidence of GHLOs in humans is low (Baele et al. 2009). On the other hand, studies on undomiciled cats show that the most common Helicobacter species in humans, H. pylori, is not detectable in the gastric mucosa of undomiciled cats and is only found in pet cats; this finding is suggestive of anthropozoonosis (Erginsoy et al. 2006). In this study the identification of the species was not performed, but was observed large helicoidal bacterias suggesting that was GHLOs.

Research involving the genus Helicobacter and its species in various colonized animals, shows that the pathogenic potential of these bacteria varies, however with ability to cause changes in the gastric mucosa that can lead to more serious conditions such as cancer. De Bruyne et al. (2012) demonstrated the ability of $H$. suis to cause gastritis in piglets, and Lee et al. (1992) demonstrated the ability of $H$. felis to cause gastritis in dogs. Studies show that the stomach of nonhuman primates is colonized by Helicobacter spp. but their pathogenic potential is still under study (De Mello et al. 2005, Lopes et al. 2013). In studies involving $H$. pylori, it was possible to show that this species is the most common Helicobacter in the human stomach (Baele et al. 2009) and to demonstrate its ability to cause gastritis, ulcers, and neoplasia (Backert and Clyne 2011). In this study, $87.5 \%$ of the animals showed histopathological changes in the gastric mucosa. Of these, $78.1 \%$ achieved mild score and $9.4 \%$ moderate score. No animal had severe score, being probable that the studied cats were more adapted to the Helicobacter species present in their gastric mucosa, being less affected. However, other studies show that not only the most common species that colonizes a population can cause gastric lesions but so can other species, as demonstrated by Joosten et al. (2013), who reported the ability of $H$. suis to cause gastritis in humans. As studies are being conducted, a greater understanding is achieved of how gender influences the phenomena in question. This knowledge is expected to facilitate the development of better gastritis treatments for various species.

\section{CONCLUSIONS}

Cats of blood group A are often colonized by Helicobacter spp. and the macroscopic and microscopic changes are similar to those reported in other studies on cats.

The presence of inflammatory infiltrate found in cats of blood A group infected by Helicobacter sp., show no correlation between the colonization score of the gastric regions, which is the same results observed in others researches.

According to our present results, the blood group most common in cats is not associated with high susceptibility to symptomatic gastritis.

Despite the low transmission rate between humans and felines, deep understanding of GHLOs should result in the development of effective gastritis treatments for the various mammals that are infected with these bacteria.

Acknowledgments.- The authors wish to thank the Coordination of Improvement of Higher Education Personnel (CAPES) Brazil for financing the research. The study sponsors had no involvement in the study design; in the collection, analysis and interpretation of data; in the wri- ting of the manuscript; and in the decision to submit the manuscript for publication.

Conflict of interest.- The authors do not have any potential conflicts of interest to declare.

\section{REFERENCES}

Akhtardanesh B., Jamshidi S., Sasani F., Mohammadi M., Bokaee S. \& Salehi T.Z. 2006. Helicobacter spp. infection and gastric lesions in domestic and stray cats. Vet. Archiv 76(6):479-488.

Araujo I.C., Mota S.B., Aquino M.H.C. \& Ferreira A.M.R. 2010. Helicobacter species detection and histopathological changes in stray cats from Niteroi, Brazil. J. Feline Med. Surg. 12:509-511.

Backert S. \& Clyne M. 2011. Pathogenesis of Helicobacter pylori Infection. Helicobacter 16:19-25.

Baele M., Pasmans F., Flahou B., Chiers K., Ducatelle R. \& Haesebrouck F. 2009. Non-Helicobacter pylori Helicobacters detected in the stomach of humans comprise several naturally occurring Helicobacter species in animals. FEMS Immunol. Med. Microbiol. 55:306-313.

Coelho E.A.F. \& Diniz R.S. 2010. Frequence of $\mathrm{ABO}$ and Rh blood groups in the population of Belo Horizonte-MG. Revta Bras. Anal. Clin. 42:245247.

Day M.J., Bilzer T., Mansell J., Wilcock B., Hall E.J., Jergens A., Minami T., Willard M. \& Washabau R. 2008. Histopathological standards for the diagnosis of gastrointestinal inflammation in endoscopic biopsy samples from the dog and cat: a report from the World Small Animal Veterinary Association Gastrointestinal Standardization Group. J. Comp. Pathol. 138(Suppl.1):S1-43.

De Bruyne E., Flahou B., Chiers K., Meyns T., Kumar S., Vermoote M., Pasmans F., Millet S., Dewulf J., Haesebrouck F. \& Ducatelle R. 2012. An experimental Helicobacter suis infection causes gastritis and reduced daily weight gain in pigs. Vet. Microbiol. 160:449-454.

Dieterich C., Wiesel P., Neiger R., Blum A. \& Corthesy-Theulaz I. 1998. Presence of multiple "Helicobacter heilmannii" strains in an individual suffering from ulcers and in his two cats. J. Clin. Microbiol. 36:1366-1370.

Erginsoy S.D., Sözmen M. \& Özcan K. 2006. Gastric Helicobacter-like organisms in stray cats. Acta Vet. Brno 75:91-98.

Geyer C., Colbatzky F., Lechner J. \& Hermanns W. 1993. Occurrence of spiral-shaped bacteria in gastric biopsies of dogs and cats. Vet. Rec. 133:1819.

Goh K.L., Chan W.K., Shiota S. \& Yamaoka Y. 2011. Epidemiology of Helicobacter pylori infection and public health implications. Helicobacter 16(Suppl.1):1-9.

Haesebrouck F., Pasmans F., Flahou B., Chiers K., Baele M., Meyns T., Decostere A. \& Ducatelle R. 2009. Gastric Helicobacters in domestic animals and nonhuman primates and their significance for human health. Clin. Microbiol. Rev. 22:202-223, Table of Contents.

Happonen I., Saari S., Castren L., Tyni O., Hanninen M.L. \& Westermarck E. 1996. Comparison of diagnostic methods for detecting gastric Helicobacter-like organisms in dogs and cats. J. Comp. Pathol. 115:117-127.

Hohenhaus A.E. 2004. Importance of blood groups and blood group antibodies in companion animals. Transfus. Med. Rev. 18:117-126.

Jaff M.S. 2011. Relation between ABO blood groups and Helicobacter pylori infection in symptomatic patients. Clin. Exp. Gastroenterol. 4:221-226.

Joosten M., Flahou B., Meyns T., Smet A., Arts J., De Cooman L., Pasmans F., Ducatelle R. \& Haesebrouck F. 2013. Case Report: Helicobacter suis Infection in a Pig Veterinarian. Helicobacter 18:392-396.

Lee A., Krakowka S., Fox J.G., Otto G., Eaton K.A. \& Murphy J.C. 1992. Role of Helicobacter felis in chronic canine gastritis. Vet. Pathol. 29:487-494.

Lopes C.A.A., Suzuki L.Y., Reis M.A., Mello M.F.V., Leite J.S. \& Ferreira A.M.R. 2013. Identification of Helicobacter spp. In Gastric Mucosa of Cynomolgus Monkey (Macaca fascicularis) Using The Silver Impregnation Method (Warthin-Starry Technique). Arch. Vet. Sci. 18:239-241.

Mattos D.E., Cintra J.R., de Mattos C.C.B., Nakashima F., Silva R.C.M.A., Moreira H.W. \& de Mattos L.C. 2010. ABO blood groups and Helicobacter 
pylori cagA infection: evidence of an association. J. Venom. Anim. Toxins 16:87-95.

Medeiros M.A., Soares A.M., Alviano D.S., Ejzemberg R., da Silva M.H. \& Almosny N.R. 2008. Frequencies of feline blood types in the Rio de Janeiro area of Brazil. Vet. Clin. Pathol. 37:272-276.

De Mello M.F.V., Monteiro A.B.S., Fonseca E.C., Pissinatti A. \& Ferreira A.M.R. 2005. Identification of Helicobacter sp in gastric mucosa from captive marmosets (Callithrix sp.; Callitrichidae, primates). Am. J. Primatol. 66: 111-118.

Neiger R., Dieterich C., Burnens A., Waldvogel A., Corthesy-Theulaz I., Halter F., Lauterburg B. \& Schmassmann A. 1998. Detection and prevalence of Helicobacter infection in pet cats. J. Clin. Microbiol. 36:634-637.

Neiger R. \& Simpson K.W. 2000. Helicobacter infection in dogs and cats: Facts and fiction. J. Vet. Intern. Med. 14:125-133.

Otto G., Hazell S.H., Fox J.G., Howlett C.R., Murphy J.C., O’Rourke J.L. \& Lee A. 1994. Animal and public health implications of gastric colonization of cats by Helicobacter-like organisms. J. Clin. Microbiol. 32:10431049.
Papasouliotis K., Gruffydd-Jones T.J., Werrett G., Brown P.J. \& Pearson G.R. 1997. Occurrence of 'gastric Helicobacter-like organisms' in cats. Vet. Rec. 140:369-370.

Pregel P., Rota A., Palmerini D., Guarda F. \& Appino S. 2008. Detection of Helicobacter in gastric washing of cats. J. Vet. Diagn. Invest. 20:780-782.

Scanziani E., Simpson K.W., Monestiroli S., Soldati S., Strauss-Ayali D. \& Del Piero F. 2001. Histological and immunohistochemical detection of different Helicobacter species in the gastric mucosa of cats. J. Vet. Diagn. Invest. 13:3-12.

Takemura L.S., Camargo P.L. \& Bracarense A.P. 2007. Detection and effects of Helicobacter spp. in cats. Acta Scient. Vet. 35:497-499.

Van Loon S., Bart A., den Hertog E.J., Nikkels P.G., Houwen R.H., De Schryver J.E. \& Oudshoorn J.H. 2003. Helicobacter heilmannii gastritis caused by cat to child transmission. J. Pediatr. Gastroenterol. Nutr. 36:407-409.

Washabau R.J., Day M.J., Willard M.D., Hall E.J., Jergens A.E., Mansell J., Minami T., Bilzer T.W. \& Group W.I.G.S. 2010. Endoscopic, biopsy, and histopathologic guidelines for the evaluation of gastrointestinal inflammation in companion animals. J. Vet. Diagn. Invest. 24:10-26. 